\title{
ARCHIVES DE PHILOSOPHIE
}

\author{
REVUE TRIMESTRIELLE PUBLIEÉ AVEC LE CONCOURS DU CENTRE \\ NATIONAL DE LA RECHERCHE SCIENTIFIQUE
}

TOME 36 - CAIIER 1 - JANVIER-MARS 1973

Hans-Georg GADAMER Iring FETSCHER

Francois EVAIN

Giovanni SALA

Francois RUSSO

Paul FOULKES

Jean LARGEAULT

Georges KALINOWSKI

Christophe GRZEGORCZYK

Paul VALADIER

Comptes rendus

REDACTION : LES FONTAINES - F60500 CHANTILLY

ABONNEMENTS : BEAUCHESNE, 117, RUE DE RENNES, 75006 PARIS

Prix de l'abonnement annuel (4 cahiers):

France: $50 \mathrm{~F}$-Etranger $60 \mathrm{~F}$

C.C.P. Beauchesne, PARIS 39-29
Heidegger et le langage de la métaphysique.

Modeles d'orde international.

Lhomme, signe de l'être dans

PAnthropologie Morale d'A. Rosmini.

La metaphysique comme structure heuristique selón Bernard Lonergan. (Suite)

Archéologie du savoir de Michel Foucault.

thérité.

Une théorie nominaliste de la proposition.

La Logique et son histoire.

F rentowski (1808-1869).

Bulletin nietzschéen.

\section{DIALOGUE}

\section{Canadian Philosophical Review - Revue Canadienne de Philosophie}

\author{
Editors: Venant Cauchy and Martyn Estall
}

VOL. XII-1973-No. 1

\section{ARTICLES}

Maine de Biran: une anthropologie transcendentale Roch Bouchard

Maine de Biran: Une critique des théories physiologiques ..... Serge J. Morin Valeurs économiques et liberté Yvon Blanchard

Considérations sémantiques sur la logique de la fiction John Woods

Commentaires sur le texte de John Woods Yvon Gauthier

Objects as Universals: A Re-appraisal of the Tractatus

Eike-Henner W. Kluge

How Brains Think David Coder

Hume's Scepticism Wade L. Robison

Are There Really Two Logics? E. J. Ashworth Kant, Husserl et l'histoire de la logique Jaromir Danek

\section{NOTES - DISCUSSIONS - REVIEWS}

\section{Subscriptions: $\$ 12.00$ a year}

Payable to the Canadian Philosophical Association in care of Norman J. Brown, Department of Philosophy, Queen's University, Kingston, Ontario, Canada 


\section{JOURNAL OF PHILOSOPHICAL LOGIC}

Editor-in-Chief: Bas C. Van Fraassen, University of Toronto, Toronto, Ontario, Canada.

\section{Contents of Volume 2, No. 1}

Lennart Aqvist / Modal Logic with Subjunctive Conditionals and Dispositional Predicates. Krister Segerberg / Two-Dimensional Modal Logic. Frederic B. Fitch / A Correlation Between Modal Induction Principles and Properties of Relations. James W. Garson / Indefinite Topological Logic. Nicholas Rescher and Arnold vander Nat / On Alternatives in Epistemic Logic. T. J. Smiley / What is a Syllogism? J. M. Bell / What is Referential Opacity?

Subscription price per volume of four issues (approx. 500 pages) Dfl. 100, (US $\$ 32.50$ ), including postage. One volume is published yearly. Personal subscription price on request.

\section{REIDEL PUBLISHING COMPANY \\ P.O. BOX 17 DORDRECHT-HOLLAND}

\section{PHILOSOPHY}

The Journal of The Royal Institute of Philosophy

VOL. 48, No. 184

APRIL 1973

EDITORIAL

Radical Philosophy

The Concept of Beastliness

Mary Midgley

Normality

Peter Alexander

Method and Insight

R. W. Hepburn

'Because you're a Woman'

J. R. Lucas

Time and Time Again

T. E. Wilkerson

\section{DISCUSSION}

On Unconscious Intentions Donald Gustafson

Flew, Strawson and Locke's Parrot James Moulder

Cosmology and Infinity Pamela M. Huby

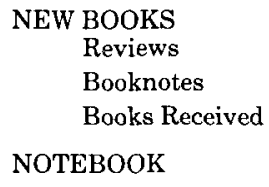




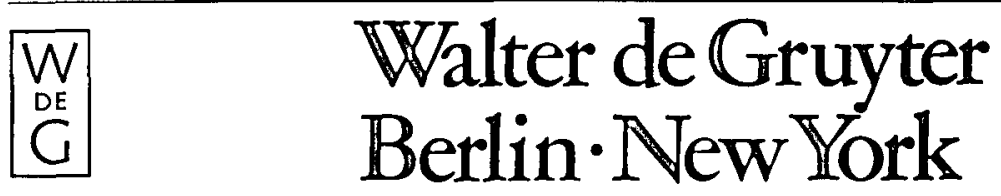

Olof Gigon

Studien zur antiken Philosophie

Edited by Andreas Graeser

$\mathrm{VI}+442$ pp. 1972. Cloth $\$ 35.00$ ISBN 3110039281

Michael Wolff

Fallgesetz und Massebegriff

Zwei wissenschaftshistorische Untersuchungen

zur Kosmologie des Johannes Philoponus

$\mathrm{X}+159$ pp. 1971. Cloth \$11.45 ISBN 3110064286

(Quellen und Studien zur Philosophie 2)

Burkhard Tuschling Metaphysische und transzendentale Dynamik in Kants opus postumum

XII + 224 pp. 1971. Cloth \$17.45 ISBN 3110018896

(Quellen und Studien zur Philosophie 3)

Hans Werner Arndt Methodo scientifica pertractatum

Mos geometricus und Kalkülbegriff in der philosophischen

Theorienbildung des 17 . und 18. Jahrhunderts

VIII + 170 pp. 1971. Cloth $\$ 23.20$ ISBN 3110039427

(Quellen und Studien zur Philosophie 4)

For USA and Canada: Please send all orders to Walter de Gruyter Inc., 162 Fifth Avenue New York, N.Y. 10010

\section{SYNTHESE}

\section{An International Journal for Epistemology, Methodology and}

Philosophy of Science

Editor-in-Chief: Jaakko Hintikka, Academy of Finland and Stanford University

Review Editor: Dagfinn Follesdal, University of Os/o

Associate Editor: Risto Hilpinen, University of Turku

Editorial Assistant: Juha Manninen, $\mathrm{He} / \mathrm{sinki}$

\section{Contents of Vol. 25, Nos. 1/2 November/December 1972}

D. A. Gillies / Operationalism. Ilkka Niiniluoto / Inductive Systematization: Definition and a Critical Survey. James W. Cornman / Craig's Theorem, RamseySentences, and Scientific Instrumentalism. Frederick Suppe / Theories, Their Formulations, and the Operational Imperative. Raimo Tuomela / Model Theory and Empirical Interpretation of Scientific Theories. Robert L. Causey / Uniform Microreductions.

Reviews: Analysis of Theories and Methods of Physics and Psychology, Minnesota Studies in the Philosophy of Science, Vol. IV (ed. by Michael Radner and Stephen Winokur) (Michael Martin). Wolfgang Stegmuller, Probleme und Resultate der Wissenschaftstheorie und Analytical Philosophie, Band II: Theorie und Erfahrung (Robert L. Causey). Jaakko Hintikka and Patrick Suppes (eds.), Information and Inference (Ernest W. Adams). Norwood Russell Hanson, Perception and Discovery (Peter Achinstein).

Subscription price per volume of four issues Dfl. 100, (US $\$ 32.50$ ), including postage. About six issues are published yearly. Personal subscription price on request.

\section{REIDEL PUBLISHING COMPANY \\ P.O.BOX 17 DORDRECHT-HOLLAND}




\section{PHILOSOPHICAL STUDIES}

\section{An International Journal for Philosophy in the Analytic Tradition}

Editor: Wilfred Sellars, University of Pittsburgh, U.S.A.

Board of Consulting Editors: David Braybrooke, Dalhousie University. Canada: May Brodbeck, University of Minnesota, U.S.A.; L. J. Cohen, Queens College, Oxford, England; James Cornman, University of Pennsylvania; U.S.A.; Alan Donagan, University of Chicago. U.S.A.; Herbert Feigl, University of Minnesota, U.S.A.; Rudolf Haller, University of Graz, Austria; Mary Hesse, University of Cambridge, England; Risto Hilpinen, University of Turku, Finland; John Hospers, University of Southern California, U.S.A.; Keith Lehrer, University of Rochester, U.S.A.; R. M. Martin, New York University, U.S.A.; Gunther Patzig, University of Gottingen, West Germany: A. M. Quinton, New College, Oxford, England; Judith Thomson, Massachussefts institute of Technology, U.S.A.

\section{Contents of Volume 23, No. 6}

C. A. Hooker / Definite Descriptions. Robert F. Ladenson / Wolff on Legitimate Authority. Kenneth T. Barnes / Hintikka's Argument for the Need for Quantifying into Opaque Contexts. George Englebresten / Persons and Predicates. Jeffry Pelletier / Sortal Quantification. Joseph Margolis / The Problem of Justified Belief. Robert J. Swartz / Identity, Indiscernibility, and Belief. Charles E. Cardwell / $A$ Note on Putnam and the Transitivity of the Real. Charles B. Daniels / A Note on Ethical Egoism. George Englebretsen / A Revised Category Mistake Argument. Richard W. Eggerman / Invertibility Revisited. Millard Schumaker / Deontic Morality and the Problem of Supererogation.

Subscription price per volume of six issues Dfl. 95, (US $\$ 30.20$ ) including postage. One volume is published yearly. Personal subscription price on request.

\section{REIDEL PUBLISHING COMPANY}

\section{P.O. BOX 17 DORDRECHT-HOLLAND}

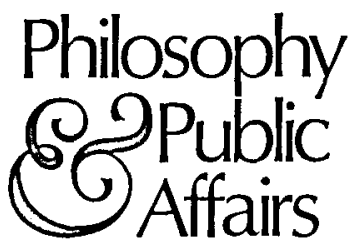

Advisory Editors

Stuart Hampshire

John Rawls

Editor

Marshall Cohen

Associate Editors

Thomas Nagel

Thomas Scanlon

Princeton University Press

P.O. Box 231

Princeton, New Jersey 08540

U.S.A.
Philosophy \& Public Affairs provides a format for in-depth discussion by philosophers of different viewpoints and philosophically inclined writers from various disciplinesincluding law, political science, economics and sociology-of issues of public concern. Recent articles include The Linguistics of Suicide, by David Daube; Hage/'s America, by G.A. Kelly; Abortion and Infanticide, by Michael Tooley; and Policy Science: Analysis or Ideology? by Laurence Tribe.

\section{$\$ 7.50$ a year $\cdot \$ 12.50$ two years}

$\$ 17.00$ three years

$\$ 10.00$ a year for institutions

\section{$\$ 2.50$ single issues}

$\$ .75$ handling charge on foreign orders 

Philosophy and the Social Sciences

Edited by Arne Naess and Alastair Hannay

Action: Description or Explanation?

(Robert Borger and Frank Cioffi

[Eds.], Explanation in the

Philosophy and Social Role (Maurice

Natanson, The Journeying Self.

A Study in Philosophy and

Concepts and Society (l. C. Jarvie,

Concepts and Society)

A. R. Louch

Published Quarterly by Universitetsforlaget

P.O. Box 307, Blindern, Oslo 3. Norway

Subscription: N. kr. 75, $\$ 12.50$ (Institutions);

N. kr. $60, \$ 10.00$ (Individuals).

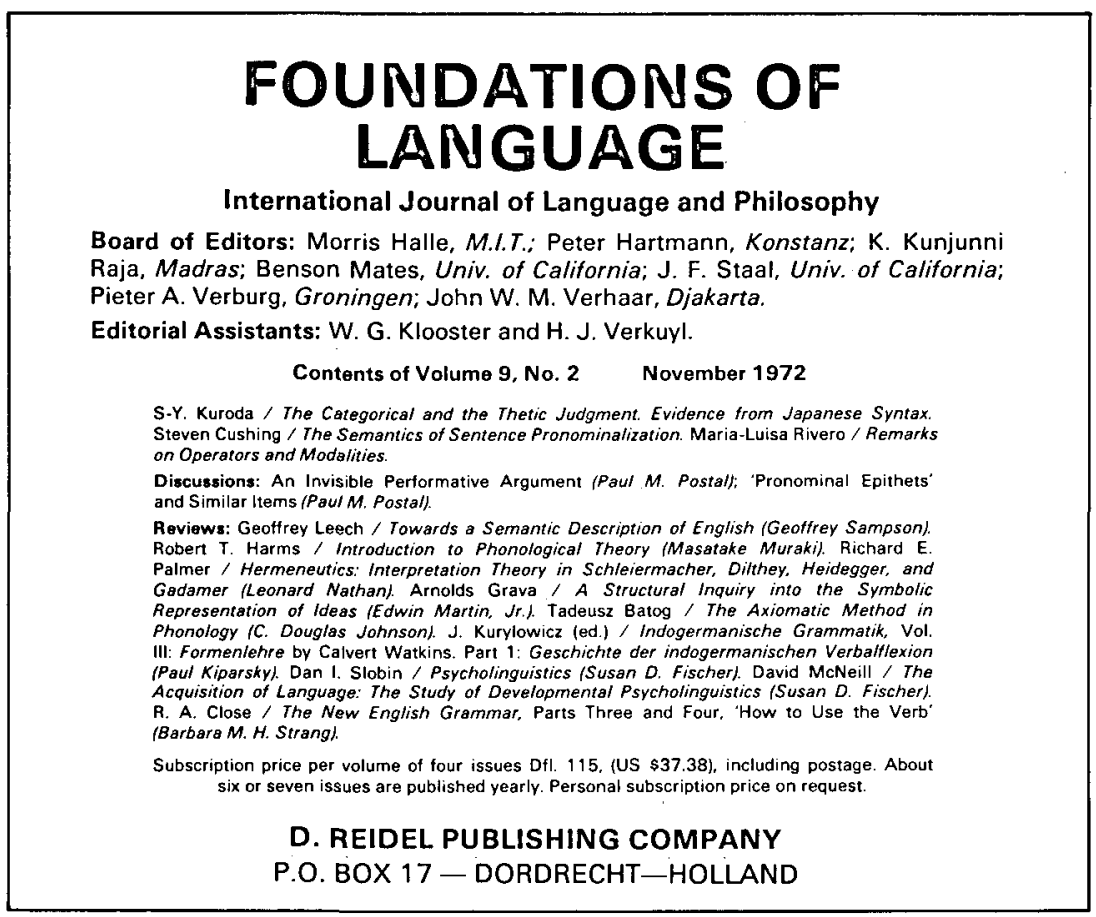




\title{
CULTURAL HERMENEUTICS
}

\section{Willowdale, Ontario}

Editor: David M. Rasmussen, Boston College, Chestnut Hill, Mass., U.S.A.

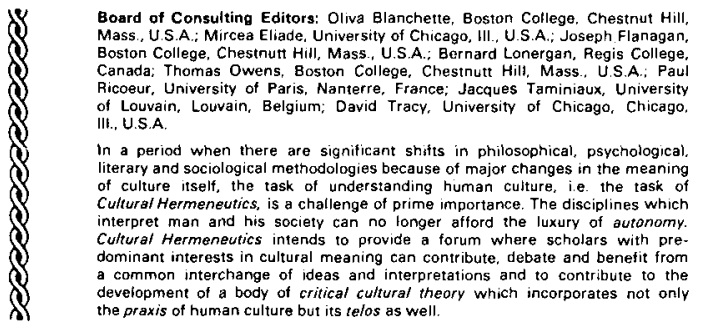

Contents of Volume 1, No. 1-September 1972

Editorial Statement. David M. Rasmussen / Between Autonomy and Sociality. Joseph J. Kockelmans / On Myth and hs Relationship to Hermeneutics. Bernard Lonergan / Merging Horizons: System, Common Sense, Scholarship. Mircea Eliade / The Sacred in the Secular World.

Subscription price per volume of four issues Dfl, 75,- (US \$24.38), including postage. One volume will be published yearly.

\author{
D. REIDEL PUBLISHING COMPANY \\ P.O. BOX 17 DORDRECHT-HOLLAND
}

\section{THEORY AND DECISION}

\section{An International Journal for Philosophy and Methodology of the Social Sciences}

Editors: G. L. Eberlein, University of Saarland, Saarbrücken; W. Kroeber-Riel, University of Saarland, Saarbrücken; W. Leinfellner, University of Nebraska, Lincoln; A. C. Michalos. University of Guelph, Guelph.

\section{Contents of Volume 3, No. 2 December 1972}

R. Duncan Luce / Conditional Expected, Extensive Utility. Rainer Potzsch / Decision-Theoretic Aspects of Risk-Taking Behaviour. Fred S. Roberts / What if Utility Functions Do Not Exist? G. W. von Wright / The Logic of Preference Reconsidered.

Discussions: Rescher's Determination of a Social Preference Ranking (Marten Ringbom). Some Observations on Social Consensus Methodology (Nicholas Rescher).

Reviews: Edward Banfield, The Unheavenly City: The Nature and Future of Our Urban Crisis (Sid Herzig). Thomas R. Dye and L. Harmon Zeigler, The Irony of Democracy: Un Uncommon Introduction to American Politics (Sidney J. Herzig). Herbert $\mathrm{H}$. Hyman and Eleanor Singer, Readings in Reference Group Theory and Research (Karl-Dieter Opp). Imre Lakatos and Alan Musgrave (eds.), Criticism and the Growth of Knowledge (Michael E. Ruse). Gerard Radnitzky, Contemporary Schools of Metascience (K. B. Madsen). H. Selsam, D. Goldway, and H. Martel (eds.), Dynamics of Social Change: A Reader in Marxist Social Science (John McMurtry). Georg Henrik von Wright, The Logic of Preferences (Sighard Roloff). Books Received.

Subscription price per volume of four issues Dfl. 85, (US \$27.63), including postage. Five or six issues are published yearly. Personal subscription price on request.

\section{REIDEL PUBLISHING COMPANY \\ P.O. BOX 17 DORDRECHT-HOLLAND}

